UJBM, Vol. 8, No. 1, January - June 2009, pp 8-19

ISSN 0975-3311 | https://doi.org/10.12725/ujbm.14.2

\title{
ASSOCIATION BETWEEN NATURE OF INDUSTRY AND EMPLOYEE'S PERCEPTION OF QUALITY OF WORK LIFE
}

\author{
S.Varadaraj* \& V.Parthiban**
}

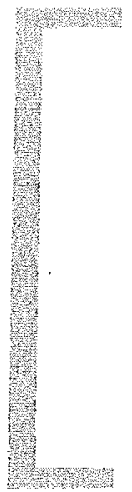

\section{ABSTRACT}

One of the major problems facing both developing and developed countries is the Quality of Work Life of a vast majority of employees engaged in productive pursuits. This issue is not just one of achieving greater human satisfaction but it also aims at improving productivity, adaptability and overall effectiveness of organisations. The recognised purpose of Quality of Work Life is to change the climate at work so that the human-technological-organisational interface leads to a better Quality of Work Life and eventually to an improved quality of life in community and society. Enhancement of Quality of Work Life also

* Lecturer in Management, Gobi Arts \& Science College, Gobichettipalayam - 638 453. Phone Home: 04285 241268, Phone Officer: 04285 240147, Cell: 9865999208, e-mail : varadarajgobiarts@yahoo.co.in

** Lecturer in Management, Gobi Arts \& Science College, Gobichettipalayam - 638 453, Phone Home: 04285 241584, Phone Officer: 04285 240147, Cell: 9443780055 , e-mail: parthibanmali@yahoo.com 
paves the way for the country to keep pace with global level development. This paper highlights the association of the perception of Quality of Work Life of Employees classified based on level of skill and nature of Industry in Coimbatore District. Chi-square test and Phi coefficient were calculated to identify the association and the magnitude of association between the variables.

\section{Introduction}

Quality of Work Life has assumed increasing interest and importance in both industrialised as well as developing countries of the world. In India, its scope seems to be broader as many labour acts have been enacted to protect the workers. It is more than a sheer work organisation movement which focuses on job security and economic growth of the employees.

The overriding purpose of a Quality of Work Life programme is to change and improve the work climate so that the interface of people, technology, and the organisation makes for a more favourable work experience and desired outcomes. Work plays a central role in the life of people engaged in productive pursuits. The nature of work one is involved with has, therefore, a profound impact on shaping not only his personality or determining his performance level in the organisation but also on his commitment to his fellow beings in the society. Thus, it is imperative to bring about improvement in the quality of life at work which can and even does lead to qualitative improvement in other facets of one's life. The prevailing socio-cultural conditions in India leave no option but to bring about such a change.

Various approaches have been adopted in different socio-cultural contexts to improve the Quality of Work Life such as quality circles, team work, autonomous group working, flexitime and self-management. Central to all these approaches has been the direct participation of employees in affairs relating to their work leading to increased autonomy, self-control and selfdirection.

\section{Review of related studies}

It is noteworthy that employees perception of Quality of Work Life varies based on demographic and organisational variables. Understanding this perception would help the leaders of the industries to work on improving the Quality of Work Life. 
Rice (1985) emphasised the relationship between work satisfaction and Quality of people's lives. He contended that work experiences and outcomes can affect person's general Quality of life, both directly and indirectly through their effects on family interactions, leisure activities and levels of health and energy.

The study conducted by Karrir and Khurana (1996) found significant correlations of Quality of work life of managers from three sectors of industry viz., Public, Private and Cooperative, with some of the background variables (education qualification, native/migrant status, income level) and with all of the motivational variables like job satisfaction and job involvement. Herrick (1981) in his study found disagreement among groups (supervisors, managers, local union officers, rank and file workers, middle managers) regarding pay and compensation.

In a study, Sirota (1973) found that underutilization of worker's skill and abilities cause low Quality of Work Life and suggested job enrichment programme to correct the problems of worker's skill and abilities. Trist (1981) suggested that there should be optimum level of autonomy according to requirements of technology system.

Singh and Pestonjee (1974) studied the differential effect of supervisory behaviour on job satisfaction those are under employee-oriented supervision. There are evidences that indicate relationship of supervisor and subordinate (Levine, 1984) and good leadership on the part of the supervisors (Schlesinger and Oshry, 1984) as important factor for worker's motivation and personal satisfaction.

\section{Study area}

In the modern industrial scenario, it is imperative for any employer to provide good human, technological and organisational climate which leads to good Quality of Work Life to ensure job performance, higher productivity, job satisfaction, job involvement and a sense of competence among employees.

In the industrial sector, Textile and Engineering industries are the major players which not only account for huge production and export but also they are the big employment providers. The study of Quality of Work Life in these two sectors is of great relevance which may help understand the 
overall Quality of Work Life in Indian industry. As Coimbatore District is highly industrialised with labour intensive units, it was selected as the study area.

\section{Objectives of the study}

The present study was undertaken with the following objectives:

1. To assess the influence of personal and institutional factors on the Quality of Work Life of employees in the industries;

2. To compare the Quality of Work Life that prevails in Engineering and Textile industries; and

3. To suggest the measures to improve the Quality of Work Life in the two industries.

\section{Hypothesis of the study}

Ho: There is no significant association between the opinions on Quality of Work Life of the respondents classified based on level of skill and the nature of industry.

\section{Research instrument}

A structured, non-disguised interview schedule was prepared for the purpose of collecting the data. The factors of the study were drawn out from the related studies and the statements of the schedule were framed representing the factors. These were given shape in consultation with the field experts. The survey was preceded by a pilot study.

\section{Population and sample profile}

The study was confined to Coimbatore District of Tamil Nadu and the data were collected from 500 employees each from Engineering and Textile industries. These employees were drawn from five concerns according to the number of employees. A Non-probability, proportionate quota sampling was used for the study. 


\section{Analysis of data}

The data collected from the primary source were entered and checked for transcription errors. Then analyses were made using the statistical package SPSS 11.0. The collected data are converted into numerical score indicating the opinion. For the purpose of analysis, based on the total scores of each respondent, they were grouped into two categories viz., satisfied respondents and dissatisfied respondents. Analysis of the significance of association between the opinions on Quality of Work Life of the respondents classified based on level of skill and the nature of industry was worked out by using Chi-square test. Phi coefficient was also calculated to identify the magnitude of association between the variables.

The respondents working in the industries were divided according to their level of skill into four categories viz., supervisors, skilled, semi-skilled and unskilled. It was kept in mind that the respondents might have different environmental conditions and nature of work and their satisfaction level under each of the category might be different according to their employment. Based on level of skill, the respondents of both engineering and textile industries were classified and the opinion of each category of respondents were depicted in the below table.

Table 1: Level of Skill and opinion on QWL

\begin{tabular}{|c|c|c|c|c|}
\hline \multirow{2}{*}{$\begin{array}{l}\text { Sl. } \\
\text { No. }\end{array}$} & \multirow{2}{*}{ Level of skill } & \multicolumn{2}{|c|}{ No. of Respondents } & \multirow{2}{*}{ Total } \\
\hline & & Satisfied & Dissatisfied & \\
\hline 1. & Supervisor & $75(48.4)$ & $80(51.6)$ & $155(100)$ \\
\hline 2. & Skilled & $130(47.3)$ & $145(52.7)$ & $275(100)$ \\
\hline 3. & Semi-skilled & $188(55.1)$ & $153(44.9)$ & $341(100)$ \\
\hline 4. & Unskilled & $103(45.0)$ & $126(55.0)$ & $229(100)$ \\
\hline & Total & $496(49.6)$ & $504(50.4)$ & $1000(100)$ \\
\hline
\end{tabular}

Figures in the parentheses are percentages.

An examination of the table shows that around 50 per cent of respondents are satisfied and another 50 per cent are dissatisfied with the Quality of Work Life in their organisations. Among the respondents of semi-skilled category, 55 per cent are satisfied and among the respondents of unskilled category more or less the same percentage are dissatisfied. Among the 
supervisors and the respondents of skilled category, the percentage of dissatisfaction is more than satisfaction. The respondents' opinion regarding Quality of Work Life for each category classified based on level of skill in engineering and textile industries are discussed as under.

\section{Supervisors and their opinion}

The supervisors are those who supervise the work of the others and maintain records of the day to day activities. Though the manual work of the supervisors is less, their responsibility is more. The nature of work of the supervisors may vary from industry to industry and their satisfaction too regarding Quality of Work Life. In order to identify the association between the opinion of supervisors and the nature of industry, they were classified as under. The Chi-square test was applied.

Table 2 : Classification of Supervisors according to their opinion

\begin{tabular}{|c|c|c|c|c|}
\hline \multirow{2}{*}{$\begin{array}{l}\text { SI. } \\
\text { No. }\end{array}$} & \multirow{2}{*}{ Satisfaction } & \multicolumn{2}{|c|}{ No. of Respondents (Supervisors) } & \multirow{2}{*}{ Total } \\
\hline & & Engineering & Textile & \\
\hline 1. & Satisfied & $50(66.7)$ & $25(33.3)$ & $75(100)$ \\
\hline \multirow[t]{2}{*}{2.} & Dissatisfied & $24(30.0)$ & $56(70.0)$ & $80(100)$ \\
\hline & Total & $74(47.7)$ & $81 \quad(52.3)$ & $155(100)$ \\
\hline
\end{tabular}

$\chi^{2}$ Value: 20.860 df: $1 \quad$ Result: Significant at $0.01 \quad$ 'Phi': 0.367

The results show that there is a significant association between the opinion of the respondents and the nature of industry at 1 per cent level. Among the dissatisfied supervisors, 70 per cent of them belong to textile industry and the remaining 30 per cent of them belong to engineering industry. Out of the satisfied supervisors, 66.7 per cent of them belong to engineering industry and the remaining 33.3 per cent of them belong to textile industry. The Phi value (0.367) shows that there is a moderate association between the variables.

\section{Skilled respondents and their opinion}

The skilled respondents include clerical staff, cashier, electrician, shift incharge, etc. The facilities provided to the skilled respondents may vary from 
industry to industry. The satisfaction of the skilled respondents regarding Quality of Work Life may also differ according to the nature of job and the nature of industry. In order to identify the association between the opinion of the skilled respondents regarding Quality of Work Life and the nature of the industry, they were classified as under and the Chi-square test was applied.

Table 3 : Classification of Skilled respondents according to their opinion

\begin{tabular}{|l|l|c|c|c|}
\hline SI. & \multirow{2}{*}{ Satisfaction } & \multicolumn{2}{|c|}{ No. of Skilled Respondents } & \multirow{2}{*}{ Total } \\
\cline { 3 - 4 } & & Engineering & \multicolumn{1}{|c|}{ Textile } & \\
\hline 1. & Satisfied & $81(62.3)$ & $49(37.7)$ & $130(100)$ \\
2. & Dissatisfied & $52(35.9)$ & $93(64.1)$ & $145(100)$ \\
\hline & Total & $133(48.4)$ & $142(51.6)$ & $275(100)$ \\
\hline
\end{tabular}

$\chi^{2}$ Value: $19.196 \mathrm{df}: 1 \quad$ Result: Significant at $0.01 \quad$ 'Phi': 0.264

It is clear from the above table that there is a significant association between the opinion of the respondents of skilled category and the nature of industry at 1 per cent level. Among the dissatisfied respondents, 64.1 per cent of them belong to textile industry and the remaining 35.9 per cent of them belong to engineering industry. Out of the total number of satisfied respondents, 62.3 per cent of them belong to engineering industry and the remaining 37.7 per cent of them belong to textile industry. It is concluded that the satisfied respondents of skilled category are more in engineering industry than the textile industry. But the Phi value shows that the association between the two variables is fairly a weak one.

\section{Semi-skilled respondents and their opinion}

The semi-skilled employees are those who enter the industry as raw hands but they pick some work, but cannot be given full charge of any work like skilled employees. They are actively involved in the manual work and their working conditions, pay and compensation are some of the factors determining the Quality of Work Life. The opinion of the semi-skilled respondents may differ from industry to industry. In order to identify the 
Table 4 : Classification of Semi-skilled respondents according to their opinion

\begin{tabular}{|c|c|c|c|c|}
\hline \multirow{2}{*}{$\begin{array}{l}\text { Sl. } \\
\text { No. }\end{array}$} & \multirow{2}{*}{ Satisfaction } & \multicolumn{2}{|c|}{ No. of Semi-skilled Respondents } & \multirow{2}{*}{ Total } \\
\hline & & Engineering & Textile & \\
\hline 1. & Satisfied & $138(73.4)$ & $50(26.6)$ & $188(100)$ \\
\hline 2. & Dissatisfied & $41(26.8)$ & $112(73.2)$ & $153(100)$ \\
\hline & Total & $179(52.5)$ & $162(47.5)$ & $341(100)$ \\
\hline
\end{tabular}

$\chi^{2}$ Value: 73.474 df: $1 \quad$ Result: Significant at $0.01 \quad$ 'Phi': 0.464

association between the opinion of the semi-skilled respondents and the nature of the industry, Chi-square test was applied. The classification of respondents with regard to their opinion and the test results are as follows:

The Chi-square value (73.474) found in the table indicates that there is a significant association between the opinion of the respondents of semiskilled category regarding Quality of Work Life and nature of industry at 1 per cent level. Further it is concluded that among the satisfied respondents, 73.4 per cent of them belong to engineering industry and only 26.6 per cent of them belong to textile industry. But among the dissatisfied respondents of semi-skilled category, 73.2 per cent of them belong to textile industry whereas 26.8 per cent of them belonging to engineering industry. The Phi value 0.464 shows that there is a moderate association between the variables.

\section{Unskilled respondents and their opinion}

The unskilled employees are known as assistants. They do not require any kind of skill for work, (e.g., sweeper and helpers to electricians, painters, operators, carpenters, etc.). It is expected that the unskilled employees may have different opinion about the Quality of Work Life depending upon the nature of the industry. Chi-square test was applied to identify the association between the opinion of the unskilled respondents regarding Quality of Work Life and the nature of industry. The classification of respondents according to their opinion and the results are given in the following table: 
Table 5 : Classification of Unskilled respondents according to their opinion

\begin{tabular}{|c|l|c|c|c|}
\hline \multirow{2}{*}{$\begin{array}{c}\text { No. } \\
\text { No. }\end{array}$} & \multirow{2}{*}{ Satisfaction } & \multicolumn{2}{|c|}{ No. of Unskilled Respondents } & \multirow{2}{*}{ Total } \\
\cline { 3 - 5 } & & Engineering & Textile & \\
\hline 1. & Satisfied & $78(75.7)$ & $25(24.3)$ & $103(100)$ \\
& Dissatisfied & $36(28.6)$ & $90(71.4)$ & $126(100)$ \\
\hline & Total & $114(49.8)$ & $115(50.2)$ & $229(100)$ \\
\hline
\end{tabular}

$\chi^{2}$ Value: $50.411 \quad \mathrm{df}: 1 \quad$ Result: Significant at $0.01 \quad$ 'Phi': 0.469

The results show that there is a significant association between the opinion of the respondents of unskilled category and the nature of industry at 1 per cent level. Among the satisfied respondents, 75.7 per cent of them belong to engineering industry and the remaining 24.3 per cent of them belong to textile industry. Out of the total number of dissatisfied respondents, 71.4 per cent of them belong to textile industry and the remaining 28.6 per cent of them belong to engineering industry. It is concluded that more number of respondents of unskilled category of engineering industry are satisfied with regard to Quality of Work Life than that of textile industry. The Phi value 0.469 shows that there is a moderate association between the variables.

From the above, it is clear that the hypothesis framed for the study stands rejected. To be precise we may say that there is significant association between the opinions on Quality of Work Life of the respondents classified based on level of skill and the nature of industry.

The various findings reveal that in engineering industry more number of employees irrespective of the classifications based on level of skill are satisfied with Quality of Work Life whereas in textile industry more number of employees irrespective of the classification are dissatisfied. This indicates that the Quality of Work Life in engineering industry is, by and large, better than textile industry. 


\section{Suggestions}

\section{Comprehensive Induction Training}

It is suggested for both the industries to arrange for induction training which would help the new entrants to fully acquaint with the job, co-workers and organisation. This arrangement would help the new employees to settle down quickly and help to eject some of the new employees out who may not find the goings-on to their satisfaction and help them to go for some other job. The company also may not lose semi trained employees in the middle of the course.

\section{Effective Employee Counselling}

It is also suggested that the companies of both the industries may give some special attention on employee counselling. These industries normally attract many young unmarried men and women. Their lack of exposure to realities of work life and social life make them emotional and problematic. Some employees in a fit of rage may quit the job and some of them may always be problematic in the organisation. A few may become tardy and a few may go on leave without intimation. This problem needs to be addressed to by proper training and motivating and the supervisors may take up the role of counsellors. Even the companies may think of hiring professional counsellors. The employees may be encouraged to meet the counsellors in person and get counselling from them. This kind of interaction may be arranged at least once in a month.

\section{Effective Training and Development}

It is quite natural that the more enlightened employees expect the management to take some measures for their development. As the technology grows in rapid pace it is imperative to keep the employees acquainted with development and trained. It is suggested that every department may have a Training and Development Committee which may recommend the management, through the supervisor concerned, regarding the implementation of latest technology, its viability for the department, cost and benefit of training regarding new technology, the individuals identified for the training, etc., This step may keep the departments and the employees on the fast track of development. This arrangement may also provide opportunity for the self development of the employees. 


\section{Flexible Work Schedule}

The tight and rigid work schedule will always keep the employees under pressure. Sometimes, the employees may not even get the rest intervals, which he normally deserves. The employees may at times be compelled to attend a particular shift though he may have pressure to attend some personal work. Some employees may be enthusiastic to do overtime work as they may have less personal commitment. Hence it is suggested that a weekly or monthly schedule, which is flexible in nature may be evolved with the help of supervisors. The flexitime system thus framed should not be detrimental to the smooth operation of the unit. By the end of every week/ month the supervisors may discuss with employees and ask them to give their options regarding their convenient work time within the stipulated frame work.

\section{Conclusion}

Going through the various findings regarding the Quality of Work Life of both engineering and textile industries of Coimbatore, the general impression one would get is that the Quality of Work Life in engineering industry by and large, is better than textile industry. This study points out some grey areas with respect to the factors of Quality of Work Life in both the industries that need special attention. These involve both hygienic and motivational factors such as wages, promotion policy, human relations, work environment, work schedule and counselling. As both industries are in the forefront of the industrial growth and accommodate the major chunk of the work force of the country, concerted and concrete efforts for enhancement of Quality of Work Life would do a lot to improve the morale and motivation of the employees and as a result there would be improvement in the health of our Indian industry.

\section{References:}

Herrick, N. Q. (1981). The Means and end of the Work, Human Relations, July, Vol. (34) (7), pp. 611-632.

Karrir, N. and Khurana, A. (1996). Quality of work life of managers in Indian industry, Journal of the Indian Academy of Applied Psychology, Jan-Jul, 22(1 -2), pp. 19-26.

Levine, M. F. (1984). Defining Quality of Working Life, Organisational Dynamics, January, Vol. 4(1), pp. 35-46. 
Mehta, P. (1977). Employees Motivation and Work Satisfaction in Public Enterprises, Vikalpa, 2(3), pp. 233-236.

Mehta, P. (1978), Objective and Subjective Factors in Employees' Satisfaction in Life and Works, Indian Journal of Industrial Relations, 2(13), pp. 4-44.

Pierce, J. L. and Denham, R. B. (1976). Task Design: A Literature Review, Academy of Management Review, 1, pp. 83-97.

Rice, R. W. (1985). Organisational Work and the Perceived Quality of Life towards a Conceptual Model, Academy of Management Review, April, Col. 10(2), pp.296-310.

Schlesinger, L. A. and Oshry, B. (1984). Quality of Work Life and the Manager: Middle in the Middle, Organisational Dynamics, Summer, Vol. 13(1), pp. 5-10.

Singh, J. D. and Pestonjee, B. M. (1974). Supervisory Behaviour and Job Satisfaction, Indian Journal and Industrial Relations, Col. 9(3), pp. 407-416.

Sirota, D. (1973). Production and Senvice Personnel and Job Enrichment, Work Study, 22(1), January, pp. 9-15.

Trist, E. L. (1981). The Evolution of Socio-Technical Systems, Issues and Quality of Working life, Occasional Papers, No. 2, June. 